\title{
Article
}

\section{PTX Instructs the Development of Lung-Resident Memory T Cells in Bordetella pertussis Infected Mice}

\author{
Julie Tomas ${ }^{1,+}+$ C , Yoon Koo ${ }^{1,2,+}$, Dimitri Popoff ${ }^{1}$, Vilma Arce-Gorvel ${ }^{1}$, Sean Hanniffy ${ }^{1}$, Jean-Pierre Gorvel ${ }^{1, \neq(\mathbb{D}}$ \\ and Cyrille Mionnet ${ }^{1, *, \neq}$ \\ 1 Centre d'Immunologie de Marseille-Luminy (CIML), Aix-Marseille University, UM2, Institut National de la \\ Santé et de la Recherche Médicale (INSERM), U1104, Centre National de la Recherche Scientifique (CNRS), \\ UMR7280, Parc Scientifique et Technologique de Luminy, Case 906, 13288 Marseille, France; \\ tomas@ciml.univ-mrs.fr (J.T.); k.yoon21@gmail.com (Y.K.); popoff@ciml.univ-mrs.fr (D.P.); \\ arce@ciml.univ-mrs.fr (V.A.-G.); hanniffy@ciml.univ-mrs.fr (S.H.); gorvel@ciml.univ-mrs.fr (J.-P.G.) \\ 2 Laboratoire Adhesion \& Inflammation, UMR INSERM 1067, UMR CNRS 7333, Aix-Marseille Université \\ Case 937, CEDEX 09, 13288 Marseille, France \\ * Correspondence: mionnet@ciml.univ-mrs.fr \\ + These authors equally contributed to the work. \\ $\ddagger$ Co-directed this work.
}

check for updates

Citation: Tomas, J.; Koo, Y.; Popoff, D.; Arce-Gorvel, V.; Hanniffy, S.; Gorvel, J.-P.; Mionnet, C. PTX Instructs the Development of Lung-Resident Memory T Cells in Bordetella pertussis Infected Mice. Toxins 2021, 13, 632. https://doi.org/ $10.3390 /$ toxins 13090632

Received: 16 June 2021

Accepted: 30 August 2021

Published: 8 September 2021

Publisher's Note: MDPI stays neutral with regard to jurisdictional claims in published maps and institutional affiliations.

Copyright: (c) 2021 by the authors. Licensee MDPI, Basel, Switzerland. This article is an open access article distributed under the terms and conditions of the Creative Commons Attribution (CC BY) license (https:/ / creativecommons.org/licenses/by/ $4.0 /)$.

\begin{abstract}
Whooping cough is a severe, highly contagious disease of the human respiratory tract, caused by Bordetella pertussis. The pathogenicity requires several virulence factors, including pertussis toxin (PTX), a key component of current available vaccines. Current vaccines do not induce mucosal immunity. Tissue-resident memory T cells (Trm) are among the first lines of defense against invading pathogens and are involved in long-term protection. However, the factors involved in Trm establishment remain unknown. Comparing two B. pertussis strains expressing PTX (WT) or not ( $\triangle \mathrm{PTX})$, we show that the toxin is required to generate both lung $\mathrm{CD}^{+}$and $\mathrm{CD} 8^{+} \mathrm{Trm}$. Co-administering purified PTX with $\triangle \mathrm{PTX}$ is sufficient to generate these Trm subsets. Importantly, adoptive transfer of lung $\mathrm{CD}^{+}$or $\mathrm{CD}^{+}$Trm conferred protection against $B$. pertussis in naïve mice. Taken together, our data demonstrate for the first time a critical role for PTX in the induction of mucosal long-term protection against $B$. pertussis.
\end{abstract}

Keywords: Bordetella pertussis; pertussis toxin; resident memory T cells; lung; mouse

Key Contribution: The manuscript highlights a pivotal role for the pertussis toxin in generating IL-17-producing lung-resident memory $\mathrm{T}$ cell populations $\left(\mathrm{CD} 4^{+}, \mathrm{CD} 8^{+}\right.$and $\gamma \delta$ ), which expand upon recall. Our study provides a new basis for PTX-mediated immunity, with implications for vaccine design/strategies aimed at enhancing long-term protection against this important pathogen. Importantly, adoptive transfer of lung $\mathrm{CD}^{+}$and $\mathrm{CD} 8^{+} \mathrm{Trm}$ conferred protection against the bacteria in naïve mice.

\section{Introduction}

Whooping cough (pertussis) is a vaccine-preventable infectious disease caused by the gram-negative bacterium Bordetella pertussis responsible of approximately 100,000 child deaths each year worldwide [1]. The pathogenicity requires several virulence factors, which act in concert to facilitate its adherence, survival and proliferation in the respiratory tract. Among them, pertussis toxin (PTX) has been shown to contribute primarily to the severity of the disease [2]. Although ptx genes are found in closely related Bordetella species, PTX is exclusively produced by B. pertussis [3]. PTX is a member of the ADPribosylating toxin family leading to accumulation of cAMP in target cells [4]. Depending on the target cells, these disturbances may result in a variety of biological activities, including lymphocytosis [5]. Concomitantly, PTX activates innate immune responses and modulates adaptive immune responses towards a mixed Th1/Th17 balance [6-8]. For all these reasons, 
pertussis toxin (PTX) is the major antigen for establishing an immune response against this bacterium and thus the main and common component of all current pertussis vaccines.

The objective of vaccination is to enable the individual to develop specific active protection against a microbe, using the natural resources of anti-infectious immunity to generate so-called "memory" immunity. Thus, on their first encounter with pathogens, naïve $\mathrm{T}$ (Tnv) cells can differentiate into several types of T cells known as "memory" cells. These memory subtypes can be phenotypically separated into central memory (Tcm), effector memory (Tem) and resident memory (Trm) T cells [9-12]. Whereas Tem and Tcm migrate almost exclusively through blood and lymphoid tissue, Trm are restricted to non-lymphoid tissues, such as the lung, brain, skin and vaginal mucosa $[9,13,14]$. Trm can be defined by the expression of CD69, an inhibitor of S1PR1 function, that prevents cells from exiting the tissue $[15,16]$. Epithelial Trm can in addition be defined by the expression of CD103, the $\alpha \mathrm{E}$ subunit of the $\alpha \mathrm{E}-\beta 7$ integrin that is required to dock these cells to E-cadherin-expressing epithelial cells [17-19]. However, the factors regulating the generation and maintenance of Trm, and their precise characteristics and molecular imprints within non-lymphoid tissues, are not clearly understood. If they generate good systemic immunity (Tem, Tcm), current vaccines induce little or no mucosal immunity (Trm). This may therefore explain why pertussis persists as an endemic disease even in vaccinated populations. Indeed, several studies showed that protective immunity against $B$. pertussis wanes rapidly after immunization of children with current acellular vaccines (aP) $[20,21]$. Moreover, these vaccines do not prevent nasal colonization or transmission of the bacteria [22,23]. Recently, the work of KHG Mills and colleagues demonstrated that in contrast to what observed in mice immunized with whole-cell pertussis (wP) vaccines, immunization of mice with an aP failed to generate CD4 ${ }^{+}$TRM cells or to protect against nasal colonization as well as lung infection with $B$. pertussis [24]. In addition, numerous animal infection models have demonstrated the control of secondary infection by Trm [13,17]. This strategic tissue positioning gives Trm an enhanced capacity to fight reinfection over circulating memory $\mathrm{T}$ cells [25]. Thus, due to their strategic positioning there is much interest in how to optimize the local differentiation and effector function of Trm cells in order to protect peripheral barrier sites from recurrent infection.

By comparing two $B$. pertussis strains producing PTX (WT) or not ( $\triangle \mathrm{PTX})$, we demonstrate, for the first time, a pivotal role for a toxin in generating lung-resident memory $\mathrm{T}$ cell populations $\left(\mathrm{CD}^{+}, \mathrm{CD}^{+}\right.$and $\left.\gamma \delta\right)$, which expand upon recall. The most frequently generated Trm are IL-17-producing cells, which favor bacterial clearance and are localized in the lung epithelial layer, a privileged colonizing site for the bacteria. Significantly, co-administration of purified PTX with $\triangle$ PTX restored the ability to generate these Trm populations during infection.

\section{Results}

In this study, we aimed at deciphering the impact of pertussis toxin (PTX) on the immune response during $B$. pertussis infection by comparing the T cell-mediated immunity triggered by a PTX producing strain (WT) to that of a PTX-deficient, isogenic strain $(\triangle \mathrm{PTX})[26]$.

\subsection{PTX Is Required to Generate $\mathrm{CD} 69^{+} \mathrm{CD} 103^{+} \mathrm{T}$ Cell Populations}

Both strains colonized the lung of intra-nasally infected mice [26,27]. However, at days 5 and 9 post-infection (p.i.), WT-infected mice contained significantly more colonyforming units (CFU) in their lungs than $\triangle \mathrm{PTX}$-infected mice (Figure 1A), confirming that PTX improves lung colonization by $B$. pertussis during the early time points p.i $[2,26,28]$. Thereafter, there was a progressive clearance of both strains leading to their complete elimination at day 27 p.i. (Figure 1A). T cell responses are critical for protection against B. pertussis $[8,29,30]$. As shown in Figure $1 \mathrm{~B}$, the frequency of $\mathrm{CD} 62 \mathrm{~L}^{-} \mathrm{CD} 44^{+} \mathrm{CD} 4^{+} \mathrm{T}$ cells (activated $\mathrm{CD}^{+}$) was higher at day 9 p.i for the $\triangle$ PTX group than the WT group, confirming the role of PTX in delaying the adaptive immune response. However, from day 

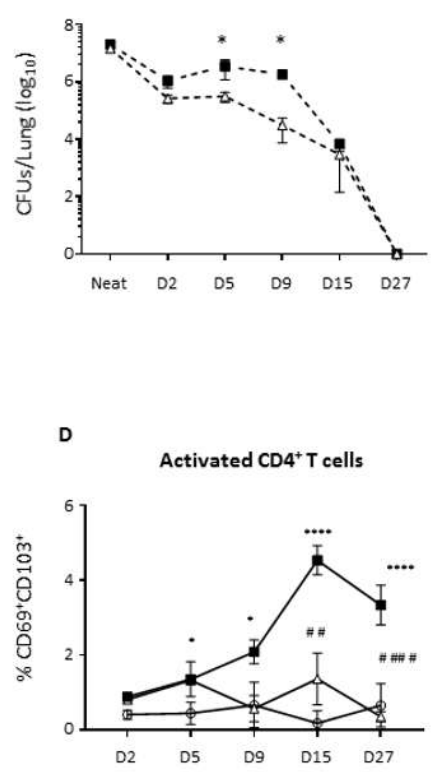

9 onwards the WT group exhibited a significant increase in the frequency of activated T cells, in contrast to the $\triangle$ PTX group (Figure 1B). In order to decipher the different subsets of $\mathrm{T}$ cells involved in immune response against $B$. pertussis, we phenotypically characterized the $\mathrm{T}$ cells by flow cytometry. As shown in Figure 1C-E, we observed a strong expansion of specific subsets expressing CD69 and/or CD103 specifically in the lung of the WT group (Figure S1). This was first evident at day 9 p.i., reaching more than $4 \%$ of active CD4 ${ }^{+}$ $T$ cells at day 15 p.i. and maintained thereafter up to day 27 p.i. (Figure 1D,E) when all bacteria were cleared (Figure 1A). These $\mathrm{CD}_{6} 9^{+} \mathrm{CD} 103^{+}$subsets were much less induced in the $\triangle$ PTX group and not maintained (Figure 1D,E).
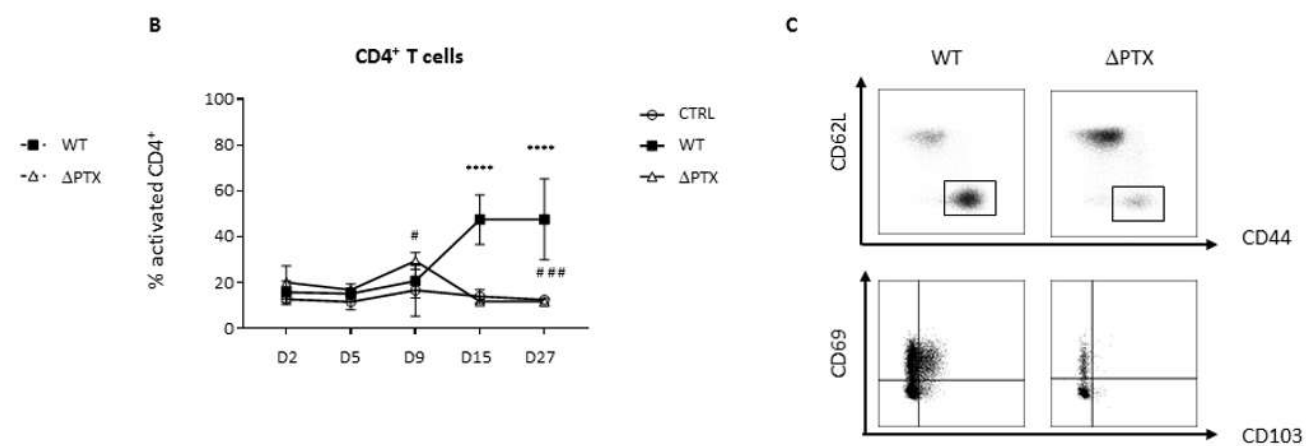

Figure 1. Pertussis Toxin (PTX) is required to generate $\mathrm{CD} 69^{+} \mathrm{CD} 103^{+} \mathrm{T}$ cell subsets in the lung of primary infected mice. (A) Numbers of colony forming units (CFU) of B. pertussis strain producing PTX (WT) or not ( $\triangle \mathrm{PTX)}$ in primary infected mice enumerated at various times post infection (p.i). Mice were intra-nasally inoculated with $6 \times 10^{6} \mathrm{CFU} / 20 \mu \mathrm{L}$ of WT or $\triangle \mathrm{PTX}$ or with $20 \mu \mathrm{L}$ of PBS (CTRL group). (B) Frequency of activated CD4 ${ }^{+} \mathrm{T}$ cells. (C) Gating strategy, frequency (D) and absolute numbers (E) of $\mathrm{CD} 4{ }^{+} \mathrm{CD} 69^{+} \mathrm{CD} 103^{+}$recorded in the lung from D2 to D27 p.i. in primary infected mice. Results are mean \pm SD for at least 4 to 5 mice/group and are representative of three independent experiments. Statistical significance of differences are shown. ${ }^{*} p$-value $<0.05 \mathrm{WT}$ vs. CTRL; ${ }^{* * *} p$-value $<0.001 \mathrm{WT}$ vs. CTRL, ${ }^{* * * *} p$-value $<0.0001 \mathrm{WT}$ vs. CTRL; $\#$ \# $p$-value $<0.01 \mathrm{WT}$ vs. $\triangle \mathrm{PTX}$, \#\# $p$-value $<0.01 \mathrm{WT}$ vs. $\triangle \mathrm{PTX}$, and \#\#\# $p$-value $<0.0001 \mathrm{WT}$ vs. $\Delta \mathrm{PTX}$.

To date, most studies concerning tissue resident lymphocytes responding to respiratory infection have focused on $\mathrm{CD}^{+} \mathrm{T}$ cells subpopulation [15,31-33]. For this reason and despite indications of an induction of $\mathrm{CD} 69^{+} \mathrm{CD} 103^{+} \mathrm{CD} 4^{+} \mathrm{T}$ cells during wild-type $B$. pertussis infection [17], we also investigated the presence of their $\mathrm{CD} 8^{+} \mathrm{T}$ cells counterpart in our experimental groups. Concomitantly to $\mathrm{CD} 69^{+} \mathrm{CD} 103^{+} \mathrm{CD} 4^{+} \mathrm{T}$ cells, we identified, to a lesser extent (7 times less compared to $\mathrm{CD} 44^{+} \mathrm{Trm}$ ), $\mathrm{CD}^{+} 9^{+} \mathrm{CD} 103^{+} \mathrm{CD} 8^{+} \mathrm{T}$ cells in the groups firstly exposed to WT (Figure S2A). During primary infection with WT, the number of $\mathrm{CD} 69^{+} \mathrm{CD} 103^{+} \mathrm{CD} 8^{+} \mathrm{T}$ cells reached the highest value at day 15 p.i. and a pool of cells was maintained at day 27 p.i. In contrast, this subset was not detected in the $\triangle$ PTX groups $(<100$ cells) (Figure S2A).

These $\mathrm{CD} 9^{+} \mathrm{CD} 103^{+}$subsets $\left(\mathrm{CD} 4^{+}\right.$and $\left.\mathrm{CD} 8^{+}\right)$have all the hallmarks of tissueresident memory cells (Trm). Of note, $\gamma \delta$ and $\mathrm{CD}^{+} \mathrm{Trm}$ cells were recently described to express CD69 and CD103 in mice during B. pertussis infection [17,34]. Moreover, these cells were described to reside at mucosal surfaces such as the lung and were able to respond rapidly to infection in the absence of $\mathrm{T}$ cell recruitment from the circulation. 


\section{2. $\mathrm{CD}_{69^{+}} \mathrm{CD} 103^{+} \mathrm{T}$ Cell Populations Expand upon New Bacteria Challenge}

To confirm the memory phenotype of our PTX-induced $\mathrm{CD} 69^{+} \mathrm{CD} 103^{+} \mathrm{T}$ cells, we tested whether an enhanced protection was observed subsequently to a re-infection. Groups of mice previously inoculated with WT or $\triangle \mathrm{PTX}$ were re-challenged by homologous or heterologous inoculation, defining 4 different groups: WT/WT, WT/ $\triangle \mathrm{PTX}, \triangle \mathrm{PTX} / \Delta \mathrm{PTX}$ and $\triangle \mathrm{PTX} / \mathrm{WT}$. In all re-challenged groups, bacteria were cleared within 5 days (Figure $2 \mathrm{~A}$ ). A time-course analysis of ongoing immunity showed an immediate $\mathrm{T}$ cell response upon infection, associated with an acute increase of $\mathrm{CD} 4^{+}$activated $\mathrm{T}$ cells in groups first infected with WT (WT/WT and WT/ $\triangle \mathrm{PTX}$ ) (Figure 2B). Most importantly, we found that among activated $\mathrm{CD} 4^{+} \mathrm{T}$ cells, there was a rapid increase in the $\mathrm{CD} 69^{+} \mathrm{CD} 103^{+}$subset from day 5 until day 9 p.i only in groups having first received WT. In this subset, $\mathrm{CD} 4^{+}$activated cells were maintained at around 5\% up to day $27 \mathrm{p} . \mathrm{i}$ (Figure 2C). These data confirm that the induction of the $\mathrm{CD} 9^{+} \mathrm{CD} 103^{+}$subset depends on a first exposure to PTX. However, this subset, which bears the hallmark of a tissue resident memory population, was not only PTX-specific due to its accelerated expansion upon reinfection with $\triangle$ PTX (Figure 2C,D).

A
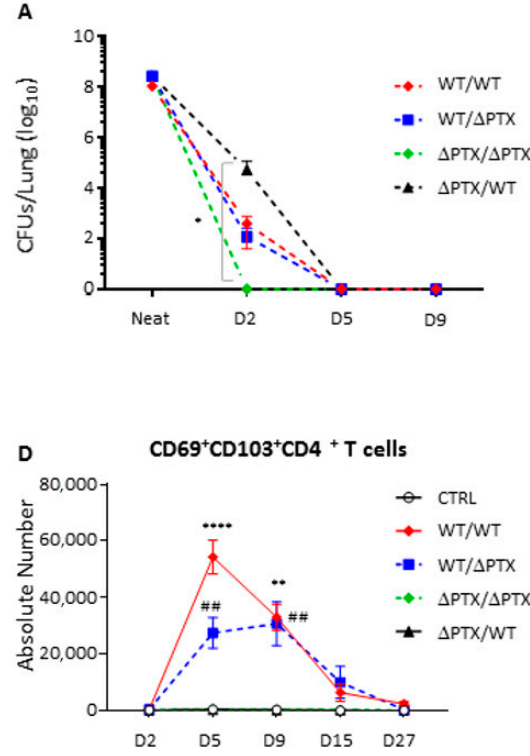

B
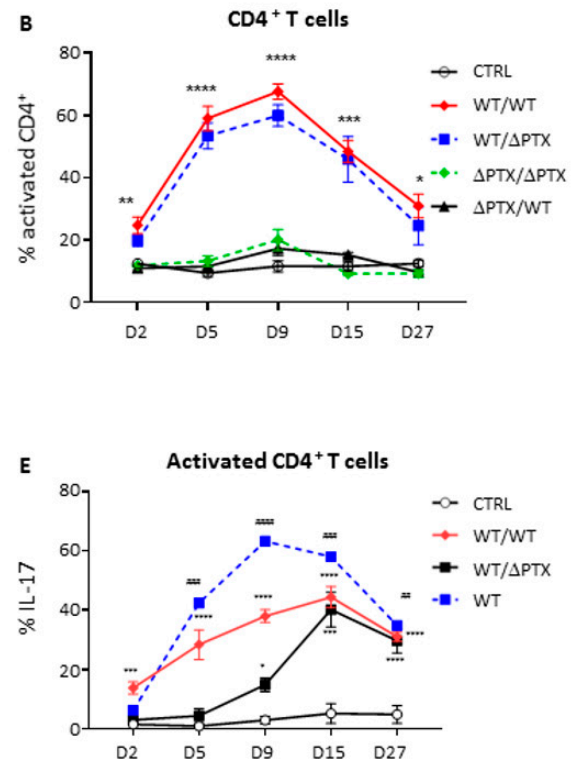

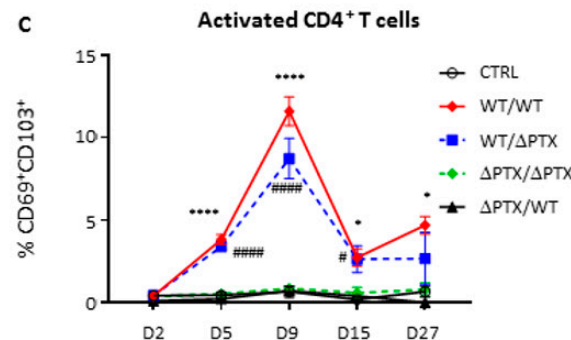

$\mathbf{F}$

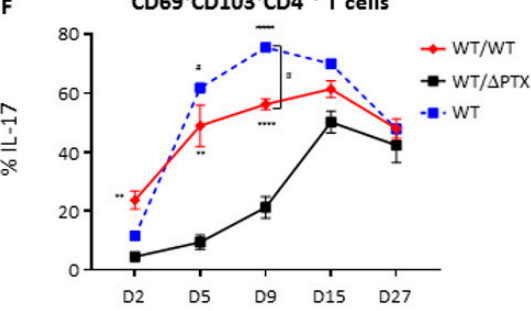

Figure 2. Recall infections lead to expansion of $\mathrm{CD} 69^{+} \mathrm{CD} 103^{+} \mathrm{T}$ cell subsets in the lung of first PTX-exposed infected mice. Mice infected twice were intra-nasally inoculated with $6 \times 10^{6} \mathrm{CFU} / 20 \mu \mathrm{L}$ of WT or $\Delta \mathrm{PTX}$ strains 6 weeks after the primary infection. (A) Numbers of CFU following a second infection from D2 to D9 p.i in WT/WT, WT/ $\triangle \mathrm{PTX}, \triangle \mathrm{PTX} / \Delta \mathrm{PTX}$ and $\triangle \mathrm{PTX} / \mathrm{WT}$ groups. Frequency of $(\mathbf{B})$ activated $\mathrm{CD} 4^{+} \mathrm{T}$ cells and $(\mathrm{C}) \mathrm{CD}^{2} 9^{+} \mathrm{CD}_{103}{ }^{+} \mathrm{T}$ cells, recorded from D2 to D27 p.i. in secondary infected mice. (D) Absolute numbers of $\mathrm{CD} 69^{+} \mathrm{CD} 103^{+} \mathrm{CD} 4^{+} \mathrm{T}$ cells. (E) Frequency of lung IL-17Aproducing $\mathrm{CD}^{+}$activated T cells, and (F) $\mathrm{CD} 69^{+} \mathrm{CD}_{103}{ }^{+} \mathrm{CD} 4^{+} \mathrm{T}$ cells harvested from $\mathrm{D} 2$ to D27 p.i. following WT, WT/WT, $\mathrm{WT} / \triangle \mathrm{PTX}$ or PBS (CTRL) inoculation. Results are mean $\pm \mathrm{SD}$ for at least 4 to 5 mice/group and are representative of three independent experiments. Statistical significance of differences are shown. For Figure $2 \mathrm{~B}-\mathrm{E} * p$-value $<0.05 \mathrm{WT} / \mathrm{WT}$ vs. CTRL, $\Delta \mathrm{PTX} / \Delta \mathrm{PTX}$ and $\Delta \mathrm{PTX} / \mathrm{WT}$; ${ }^{* *} p$-value $<0.01 \mathrm{WT} / \mathrm{WT}$ vs. CTRL, $\Delta \mathrm{PTX} / \Delta \mathrm{PTX}$ and $\Delta \mathrm{PTX} / \mathrm{WT}$, *** $p$-value $<0.001$ $\mathrm{WT} / \mathrm{WT}$ vs. CTRL, $\Delta \mathrm{PTX} / \Delta \mathrm{PTX}$ and $\Delta \mathrm{PTX} / \mathrm{WT},{ }^{* * *} p$-value $<0.0001 \mathrm{WT} / \mathrm{WT}$ vs. CTRL, $\Delta \mathrm{PTX} / \Delta \mathrm{PTX}$ and $\Delta \mathrm{PTX} / \mathrm{WT}$; \#\# $p$-value $<0.01 \mathrm{WT} / \Delta \mathrm{PTX}$ vs. CTRL, $\Delta \mathrm{PTX} / \Delta \mathrm{PTX}$ and $\Delta \mathrm{PTX} / \mathrm{WT}$, \#\#\# $p$-value $<0.01$ vs. CTRL, $\Delta \mathrm{PTX} / \Delta \mathrm{PTX}$ and

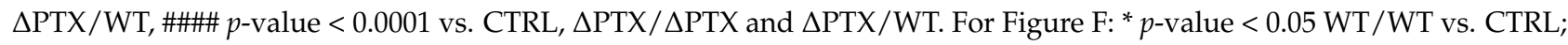
${ }^{* *} p$-value $<0.01 \mathrm{WT} / \mathrm{WT}$ vs. CTRL, ${ }^{* * *} p$-value $<0.001 \mathrm{WT} / \mathrm{WT}$ vs. CTRL, ${ }^{* * * *} p$-value $<0.0001 \mathrm{WT} / \mathrm{WT}$ vs. CTRL; \#\# $p$-value $<0.01 \mathrm{WT} / \triangle \mathrm{PTX}$ vs. CTRL, \#\#\# p-value $<0.01$ vs. CTRL, amd \#\#\# $p$-value $<0.0001$ vs. CTRL. 
More, during the recall experiments, only the WT/WT group exhibited an expansion of the $\mathrm{CD} 9^{+} \mathrm{CD} 103^{+} \mathrm{CD}^{+} \mathrm{T}$ cells from day 2 p.i. to reach the highest value at day 15 p.i. (Figure S2B). Taken together, these data underline the requirement of PTX to generate lung $\mathrm{CD} 9^{+} \mathrm{CD} 103^{+}$memory $\left(\mathrm{CD}^{+}{ }^{+} \mathrm{CD}^{+}\right) \mathrm{T}$ cell populations, with the hallmarks of a resident phenotype that expands upon recall (Figures 1 and 2).

\subsection{Trm Are Localized at the Front Line of Defense}

The tissue residency characteristics of these subsets were more closely examined in the WT/WT-group. We treated infected mice with the fingolimod FTY720 and lymphocyte egress was examined (Figure 3A). As expected, due to the high frequency of $\mathrm{CD} 69^{+} \mathrm{CD}^{+} \mathrm{T}$ cells in the WT/WT group, more $\mathrm{CD}^{+} \mathrm{T}$ cells were sequestered in the lung as compared to $\triangle \mathrm{PTX} / \triangle \mathrm{PTX}$ group upon FTY720 treatment (Figure $3 \mathrm{~B}$ ). The $\mathrm{CD}^{2} 9^{+} \mathrm{CD} 103^{+} \mathrm{CD} 4^{+}$and $\mathrm{CD}^{+} \mathrm{T}$ cells were maintained in the tissue during FTY720 treatment (Figure 3B) and proliferated during the course of infection (Figure S3A). The migratory properties of Trm allowed them to localize and expand at the front line of defense upon re-infection. While micrographs have previously shown $\mathrm{CD}^{+} \mathrm{T}$ cells to be associated with the parenchyma of tissues close to the airways and large blood vessels during $B$. pertussis infection [31], the in-situ localization of $\operatorname{Trm}\left(\mathrm{CD}^{+}\right.$and $\left.\mathrm{CD}^{+}\right)$in the lung has yet to be demonstrated. Using confocal microscopy, we found that $\mathrm{CD} 69^{+} \mathrm{CD} 103^{+} \mathrm{CD} 4^{+}$and $\mathrm{CD} 69^{+} \mathrm{CD} 103^{+} \mathrm{CD} 8^{+} \mathrm{T}$ cells localized to the epithelial layer surrounding large airways during infection (Figure 3C). Moreover, and in accordance with their kinetics of induction, there was a higher proportion of these cells present in the WT and WT/WT groups (at day 15 (data not shown) and at day 9 p.i., respectively). Despite the fact that we found very few $\mathrm{CD}^{+} \mathrm{T}$ cells within the lung of WT or $\triangle \mathrm{PTX}$ infected mice, $\mathrm{CD} 69^{+} \mathrm{CD} 103^{+} \mathrm{CD} 8^{+} \mathrm{T}$ cells were mostly localized within the lung parenchyma close to airways (Figure 3C). Using FISH technology, we also observed high frequencies of WT bacteria localized within the bronchial lumen and attached to the ciliated epithelium in the proximity of the $\mathrm{CD} 69^{+} \mathrm{CD} 103^{+} \mathrm{CD} 4^{+} \mathrm{T}$ cells (Figure S3B). Taken together, these data confirm the tissue resident memory phenotype of our $\mathrm{CD} 69^{+} \mathrm{CD} 103^{+} \mathrm{T}$ cell subsets $\left(\mathrm{CD}^{+}\right.$and $\mathrm{CD}^{+}$) (Figure 3 ) at the front line of defense against $B$. pertussis.
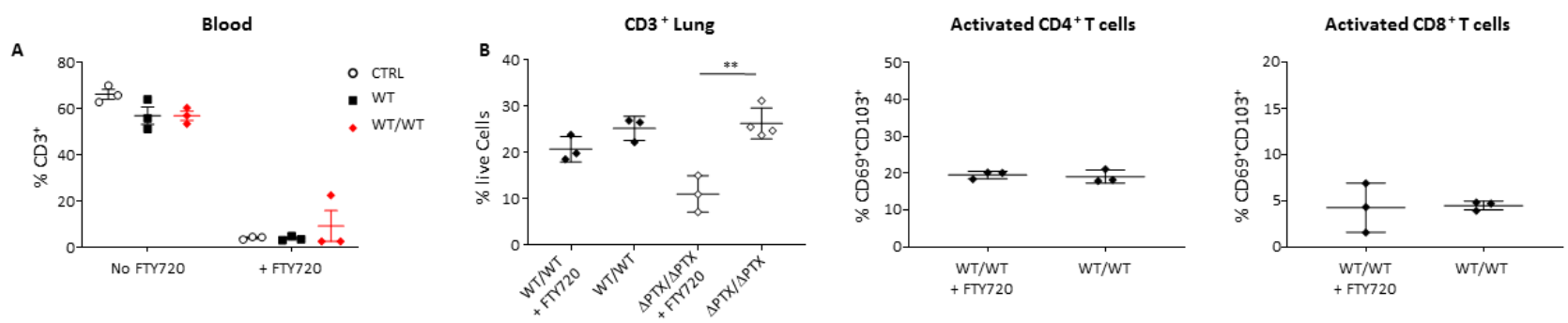

Figure 3. Cont. 


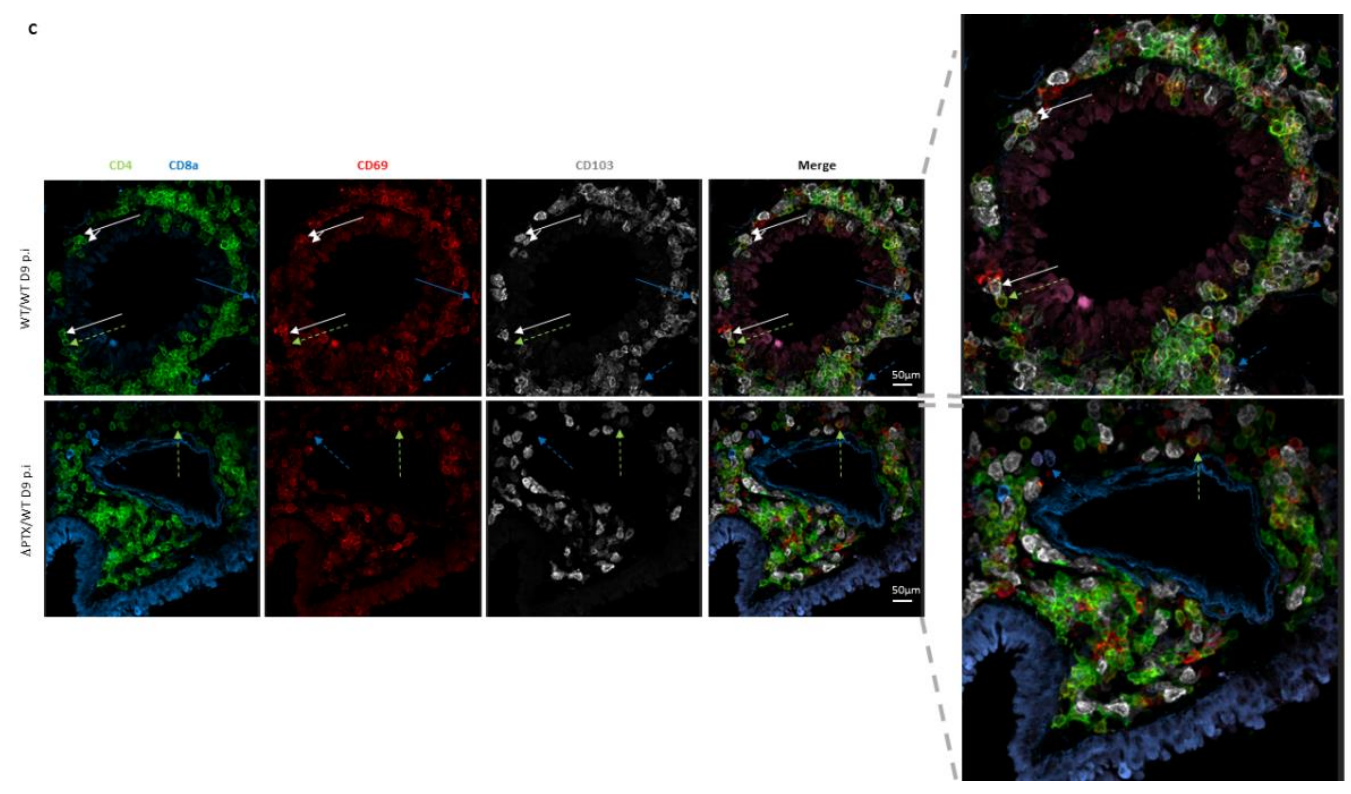

Figure 3. Residency characterization of the $\mathrm{CD} 4^{+} / \mathrm{CD}^{+}$Trm cell subsets in the lung of infected mice. (A) Frequency of $\mathrm{CD}^{+} \mathrm{T}$ cells harvested from the blood after or not treatment with FTY720 in WT, WT/WT and CRTL groups at day 5 p.i. (B) Frequency of $\mathrm{CD}^{+} \mathrm{T}$ cells and $\mathrm{CD}^{+} / \mathrm{CD}^{+}$Trm cells harvested from the lung after or not treatment with FTY720 in WT/WT group at day 5 p.i. (C) Representative micrographs of $\mathrm{CD} 4^{+} / \mathrm{CD} 8^{+}$Trm cells taken by confocal microscopy, at day 9 pi. in WT/WT and $\triangle \mathrm{PTX} / \mathrm{WT}$ infected mice. Section stained for CD4 (green), CD8 (cyan), CD69 (red) and CD103 (grey). Arrows indicate $\mathrm{CD}^{+}$(green) and $\mathrm{CD}^{+}$(blue) $\mathrm{T}$ cells. White arrows indicate $\mathrm{CD} 4^{+}$or $\mathrm{CD} 8^{+} \mathrm{Trm}$. Results are mean $\pm \mathrm{SD}$ for at least 3-4 mice/group and are representative of three independent experiments. Statistical significance of differences are shown. ${ }^{* *} p$-value $<0.01$.

\subsection{Trm Favor a Th17 Environment in the Lung of Infected Mice}

While IL-4 $4^{-/}$mice are able to clear bacteria as fast as the wild-type mice, suggesting that Th2 is dispensable, IL- $17^{-/-}$or IFN- $\gamma^{-/-}$mice are unable to do so, indicating the critical role of the Th1/Th17 immune responses in protection against B. pertussis [7]. CD4 ${ }^{+}$ $\mathrm{T}$ cells expanding locally during $B$. pertussis infection have been shown to generate a predominant Th17 microenvironment [6-8]. As shown in Figure 2E,F, IL-17 production by activated $\mathrm{CD}^{+}{ }^{+} \mathrm{T}$ cells and $\mathrm{CD} 4^{+}$Trm significantly increased during infection with WT. The frequency of IL- $17^{+} \mathrm{CD}^{+}$cells reached maximum levels at day 15 p.i. for the $\mathrm{WT}$ and WT/WT groups, and at day 9 p.i. for the WT/ $\mathrm{PTX}$ group, these time points corresponding to when the highest numbers of CD4+ Trm were observed during primary or secondary infection (Figures 1D and 2C,D). Interestingly, more than $70 \%$ and $50 \%$ of $\mathrm{CD}^{+}$Trm produced IL-17 in the WT/ $\triangle \mathrm{PTX}$ and WT/WT groups, respectively (Figure 2F), highlighting the key contribution of this Trm population to producing a Th17 environment during infection. As expected, the kinetics of induction of IL-17 production and expansion of Trm directly coincided with the clearance of bacteria in each of the relevant groups (Figures 1A and 2A). There was also an increase in IL-17-producing CD8 ${ }^{+}$Trm but again to a lesser extent than the $\mathrm{CD} 4^{+}$Trm (no more than $20 \%$ of $\mathrm{CD}^{+}$Trm were IL-17-producing) (Figure S2B). Interestingly, the magnitude of the $\mathrm{CD}^{+}$Trm response was identical during the primary or the secondary infection (Figure S2A,B), as opposed to the significant 2-fold increase response of $\mathrm{CD}^{+}{ }^{+}$Trm at recall (Figure 2C). In contrast to IL-17, the IFN- $\gamma$ profile of the $\mathrm{CD}^{+} \mathrm{T}$ cells showed no significant differences between the groups (Figure S4A). However, shortly after the infection (day 2 p.i.), $40 \%$ of $\mathrm{CD}^{+}$Trm produced IFN- $\gamma$ in the WT and WT/WT groups and then halved and maintained around 20\% from day 5 p.i. onwards (Figure S4B). The same trend was observed for IL-4 and IL-2 with the difference that on day 2 p.i. more than $90 \%$ of CD4 ${ }^{+}$Trm produced IL-4 (Figure S4B). Almost $100 \%$ of the $\mathrm{CD}^{+}{ }^{+}$Trm produced TNF- $\alpha$ during the entire course of the experiments (Figure S4B). 
This correlates with the induction of IL-17 and the inflammatory Th17 environment linked to exposure to PTX. In contrast, enhanced induction of IL-2 and IL-4 in the $\triangle \mathrm{PTX} / \triangle \mathrm{PTX}$ and WT / $\triangle \mathrm{PTX}$ groups, at day 9 p.i, suggests an early effector response that is predominantly Th1/Th2 rather than Th17 in the absence of PTX exposure. The profile of the WT/ $\triangle \mathrm{PTX}$ group seems to be a combination of the three responses Th1/Th2/Th17 in the absence of PTX during the recall phase (Figure S4A). Together, these results show that wild-type B. pertussis infection does not further favor Th1 to Th2 responses but rather reinforce the notion that protection is based on a predominant Th17 environment, in which $\mathrm{CD}^{+}$and $\mathrm{CD}^{+}$Trm are major contributors by producing IL-17 upon PTX exposure.

\subsection{PTx Is Critical to Generate Trm}

To confirm that PTX is essential for generating Trm $\left(\mathrm{CD}^{+}, \mathrm{CD}^{+}\right)$in the lung, mice were inoculated with $\triangle \mathrm{PTX}$ co-administered with purified PTX $(\triangle \mathrm{PTX}+\mathrm{pPTx})$. Surprisingly, a single dose of pPTx was sufficient to generate $\mathrm{CD}^{+}$Trm in the $\triangle \mathrm{PTX}+$ pPTX group at day 15 p.i. (Figure $4 \mathrm{~A}, \mathrm{~B}$ ). While there was notable difference in absolute numbers of $\mathrm{CD}^{+}$Trm in the $\triangle \mathrm{PTX}+\mathrm{pPTX}$ group compared to the WT group, CD4 ${ }^{+}$Trm numbers significantly increased compared to groups administered $\triangle \mathrm{PTX}$ or pPTX alone (Figure $4 \mathrm{~B}$ ). In contrast, the number of $\mathrm{CD}^{+}$Trm generated in the $\triangle \mathrm{PTX}+\mathrm{pPTX}$ group was similar to that seen in the WT group (Figure 4C). As previously shown by Misiak and colleagues, $\gamma \delta$ T cells expand during WT infection (Figure S5A-C). Surprisingly, adding pPTX to $\triangle$ PTX strain was not only sufficient to induce $\gamma \delta \mathrm{T}$ but also resulted in $\gamma \delta$ Trm expansion (Figure S5C). Altogether, these data confirm that PTX is absolutely critical to generate Trm in the lung of $B$. pertussis infected mice.

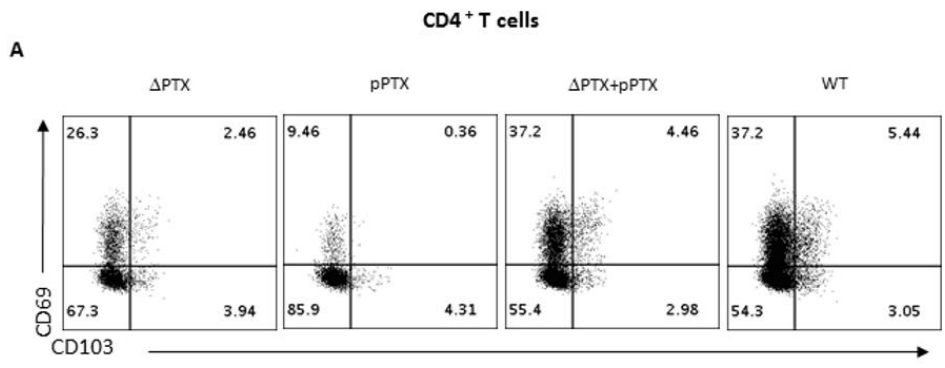

B

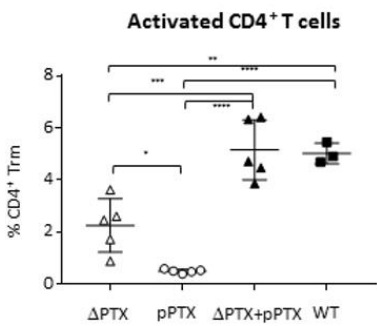

C

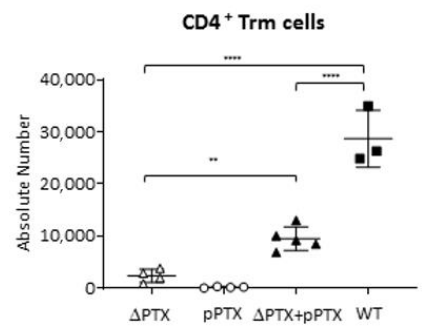

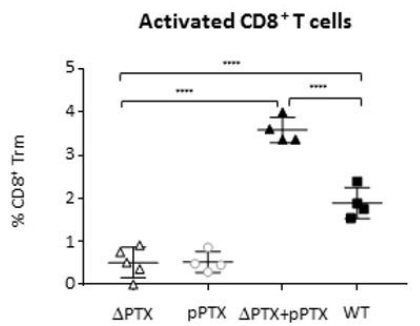

$\mathrm{CD}^{+}{ }^{+} \mathrm{Trm}$ cells

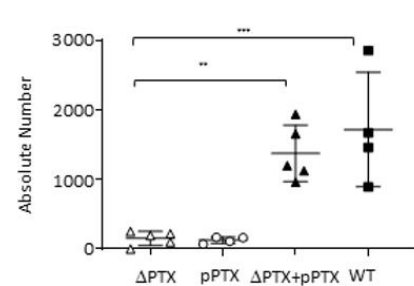

Figure 4. The generation of Trm cells is dependent on PTX exposure during B. pertussis infection. (A) Representative flow cytometry of CD69 and CD103 expression of CD62 $\mathrm{L}^{-} \mathrm{CD} 44^{+} \mathrm{CD} 4^{+} \mathrm{T}$ cells harvested from lung in $\triangle \mathrm{PTX}, \mathrm{pPTX}, \triangle \mathrm{PTX}+$ pPTX and WT groups at day 15 p.i. Frequency and absolute numbers of (B) $\mathrm{CD}^{+}$Trm and (C) CD8 ${ }^{+}$Trm harvested in the lung of $\triangle \mathrm{PTX}, \mathrm{pPTX}, \triangle \mathrm{PTX}+\mathrm{pPTX}$ and $\mathrm{WT}$ groups at day $15 \mathrm{p}$.i. Results are mean $\pm \mathrm{SD}$ for at least 3 to 5 mice/group and are representative of two independent experiments. Statistical significance of differences are shown. ${ }^{*} p$-value $<0.05$; ** $p$-value $<0.01, * * *$-value $<0.001$ and $* * * *$-value $<0.0001$.

The significant increase in lung colonization by $\triangle \mathrm{PTX}$ when co-administered with pPTX (Figure S5D) would support previous studies demonstrating a role for the toxin in delaying the immune response that facilitates colonization especially during the early stages of infection [10,11]. Paradoxically, PTX-mediated inhibition of chemotaxis [35] may 
also enable lung retention of newly activated $\mathrm{T}$ cell leading to their compartmentalization and development as Trm. De novo production and secretion of PTX during the course of infection can explain the increased numbers of Trm (in terms of absolute numbers) in the $\mathrm{WT}$ group compared to the $\triangle \mathrm{PTX}+\mathrm{pPTX}$ group.

\subsection{Trm Are Sufficient to Protect against a New Infection}

Adoptive transfer of $\mathrm{CD}^{+} \mathrm{T}$ cells into naïve mice has already demonstrated the importance of T-cell immunity in clearing B. pertussis in mice (Mills et al., 1993). To assess their role in mediating protection against PTX-producing $B$. pertussis, we adoptively transferred CD $90.2^{+}$ $\operatorname{Trm}\left(\mathrm{CD}^{+}{ }^{+}\right.$or $\left.\mathrm{CD}^{+}\right)$. We used as positive controls CD90.2 $2^{+} \mathrm{CD} 62 \mathrm{~L}^{-} \mathrm{CD} 44^{+} \mathrm{CD} 69^{+} \mathrm{CD} 103^{-}$ $\mathrm{CD}^{+}$or $\mathrm{CD}^{+}{ }^{+} \mathrm{T}$ cells. Each of these subsets were sorted from the WT/WT mice at day 9 p.i (Figure 5A). The $\mathrm{CD} 90.2^{+} \mathrm{CD}^{+} \mathrm{CD}^{2} \mathrm{~L}^{+}$(naïve $\mathrm{T}$ ) subset coming from naïve mice was also investigated as a negative control. The recipient $\mathrm{CD} 90.1^{+} / \mathrm{CD} 90.2^{+}$naïve mice once transferred were then infected with WT and protection was assessed (Figure 5A). As expected, transfer of naïve $\mathrm{T}$ cells did not significantly decrease the bacterial load at day 6 p.i. (Figure 5B). However, all the other transferred populations significantly reduced the bacterial burden in the lung of the mice at day 6 p.i. (Figure 5B). Transferred CD4 ${ }^{+}$or $\mathrm{CD}^{+} \mathrm{Trm}$ are sufficient to provide significant protection against PTX-producing WT to a similar extent to the protection conferred by activated $\mathrm{T}$ cells, which includes all effector $\mathrm{T}$ cells (Figure 5B). In our case, protection conferred by the transferred $\mathrm{CD} 4^{+}$and $\mathrm{CD} 8^{+} \mathrm{Trm}$ was probably mediated through the Th17 environment, as suggested by the ROR- $\gamma$ t plots (Figure 5C).

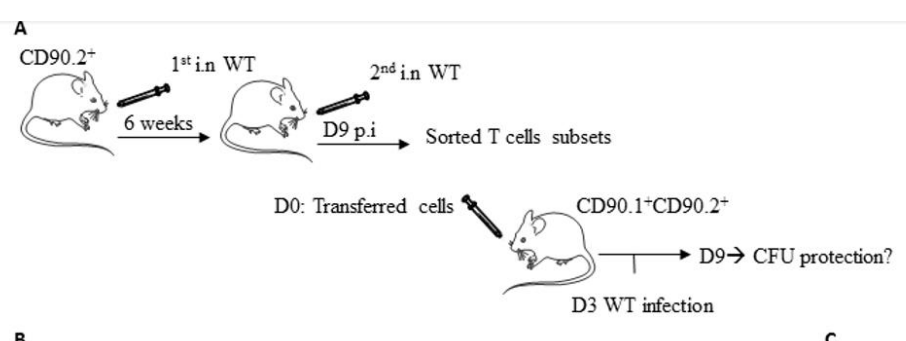

$\begin{array}{lc}\text { Transferred subsets } & \text { \# cells transferred/mouse } \\ \text { CD } 90.2^{+} \mathrm{CD} 4{ }^{+} \mathrm{Trm} & 75,000 \\ \mathrm{CD} 90.2^{+} \text {activated } \mathrm{CD} 4^{+} & 75,000 \\ \text { CD } 90.2^{+} \mathrm{CD} 8^{+} \mathrm{Trm} & 12,500 \\ \mathrm{CD} 90.2^{+} \text {activated } \mathrm{CD} 8^{+} & 12,500 \\ \text { CD } 90.2^{+} \text {activated } \mathrm{CD} 4^{+} \text {mLN } & 10,000 \\ \text { CD } 90.2^{+} \text {naive T cells } & 1,000,000\end{array}$

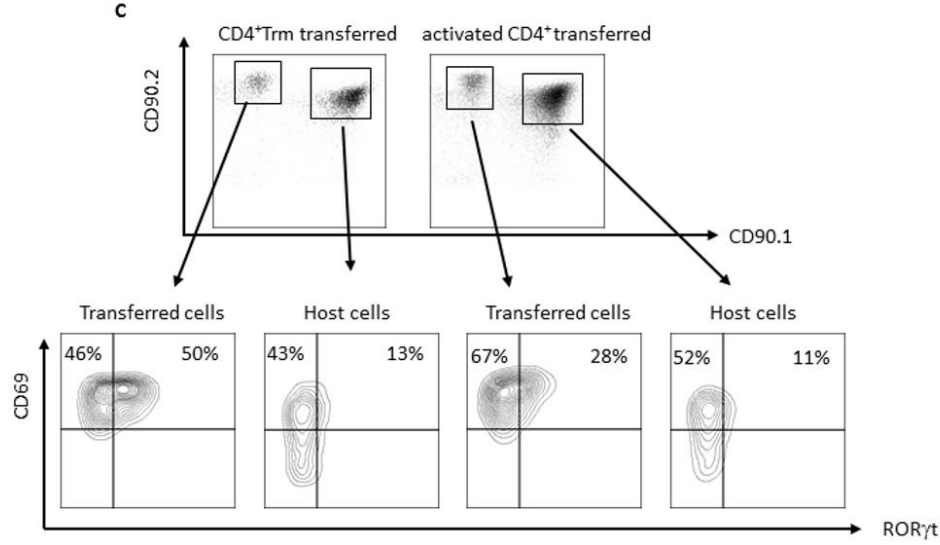

Figure 5. Transfer of Trm confers protection against B. pertussis. (A) Schematic representation of the adoptive transfer protocol and number of cells transferred in naïve CD90.1 $1^{+} \mathrm{CD} 90.2^{+-}$recipient mice. (B) Recipient mice were killed at day 6 p.i for the CFU protection analyses. Results are mean \pm SD for at least 2 to 6 mice/group and are representative of two independent experiments. All the groups were compared to the PBS control group. Statistical significance of differences are shown. ${ }^{*} p$-value $<0.05 ;{ }^{* *} p$-value $<0.01$. (C) Representative flow cytometry panels to follow transferred and host cells. CD69 and ROR $\gamma t$ expression of transferred and host cells harvested from lung of recipient mice at day 6 p.i. The upper right quadrant indicates the frequency of $\mathrm{ROR} \gamma \mathrm{t}$ positive cells. 


\section{Discussion}

To summarize, whooping cough is an important cause of morbidity and mortality in infants, young adults and seniors worldwide and continues to be a public health concern despite high vaccination coverage [36-38]. Following an increase in resurgence of the infection in developed countries using acellular vaccines, interest is now focused on mucosal memory responses generated by B. pertussis. In two previous studies, Mills $\mathrm{KH}$ et al. observed for the first-time resident memory $\mathrm{CD}^{+}$and $\gamma \delta \mathrm{T}$ cells in the lung of $B$. pertussis infected mice $[17,34]$. These cells play an important role in the protection against $B$. pertussis as they are supposed to reside physically at the first line of defense against bacteria and favor a predominant Th17 environment in the lung of infected mice. For the first time, we visualized lung $\mathrm{CD} 4^{+}$and $\mathrm{CD} 8^{+}$Trm by confocal microscopy, confirming that they can directly create a specific environment to improve immune response against a new B. pertussis infection (Figures 2E,F, 3C, 5C and S5E,F). However, what triggers these populations is not known. It is well established that CD69 antagonizes S1PR1 [16], which is required for migration of T cells out of tissues; hence, S1PR1 inhibition would facilitate tissue residency [39]. Indeed, we observed a lesser frequency of activated $\left(\mathrm{CD} 62 \mathrm{~L}^{-} \mathrm{CD} 44^{+}\right)$ and so of CD69 expressing T cells in $\triangle \mathrm{PTX}$ infected mice. Does the strength of inflammation increase the number of activated $\mathrm{T}$ cells expressing CD69 and so conversion for a part of them in Trm. To test that, we infected mice with a higher dose of B. pertussis $\triangle \mathrm{PTX}$. As shown in Figure S6, we were able to restore similar frequencies of $\mathrm{CD} 44^{+}$and $\mathrm{CD} 69^{+}$ $\mathrm{CD}^{+} \mathrm{T}$ cells. However, this did not lead to the formation of $\mathrm{CD}^{+} \mathrm{Trm}$. In the opposite, administration of a single dose of purified PTX with B. pertussis $\triangle$ PTX inoculum (Figure 4) can successfully (i) increase the frequency of activated $\mathrm{CD}^{+} \mathrm{T}$ cells (Figure S5C) and (ii) restore the level of generated $\operatorname{Trm}\left(\mathrm{CD}^{+}, \mathrm{CD} 8^{+}\right.$and $\left.\gamma \delta\right)$. This confirms that PTX directly influences the generation of Trm either via its inhibition of chemokine receptor signaling or via a synergy with other B. pertussis toxins or both. Previous reports have shown that upregulation of CD103 always occurs late during the infection process in order to affect the persistence of Trm long after the cells had reached the site of infection [40]. Indeed, this is confirmed by our experiment where mice were firstly exposed to $\triangle \mathrm{PTX}$ strain and re-challenged with the WT strain. Even in this case, we did not observe a de novo generation of Trm. This could be explained by the quick elimination of the inoculum due to other memory cells (Tem, Tcm and memory B cells). Our study leads us hypothesize that raising from the $\mathrm{CD} 62 \mathrm{~L}^{-} \mathrm{CD} 44^{+} \mathrm{CD} 69^{+} \mathrm{CD} 103^{-} \mathrm{T}$ cell subset, $\mathrm{CD} 4^{+}$and $\mathrm{CD} 8^{+}$differentiated into Trm $\left(\mathrm{CD} 62 \mathrm{~L}^{-} \mathrm{CD} 44^{+} \mathrm{CD} 69^{+} \mathrm{CD} 103^{+}\right)$only if they were first exposed to PTX due to a longer retention in infected lungs. However, it can be argued that current vaccines contain PTX, but they do not induce formation of Trm [24]. This could be due to the fact that either vaccines do not contain all the B. pertussis antigens or because they contain a modified PTX (WHO, 2016). Considering PTX as an adjuvant, its interaction with dendritic cells has also been shown to increase the adaptive response [41] and to enhance diverse lymphocyte expansion, including Th1, Th2 and Th17 responses, while reducing the number and function of regulatory T cells [42]. In addition, the eventual absence of PTX (and its adjuvant properties) following an initial administration would minimize the impact of any response that specifically targets the toxin and reduce the magnitude of the adaptive $\mathrm{T}$ cell response (including Trm) that is dependent on but not necessarily specific to PTX. Moreover, Mills KHG et al. showed in vitro that lung-isolated Trm can be re-stimulated by different antigens, but they did not demonstrate any specificity or identify a particular role for any given antigen in generating resident populations. We observed the same thing in vivo as our $\mathrm{CD}^{+}$Trm were able to expand after a second infection with $\triangle \mathrm{PTX}$ strain (Figure 2B). On the other hand, in our study we observed that the generated CD8 ${ }^{+}$Trm seem to be PTX specific. Indeed, $\mathrm{CD}^{+}$Trm did not expand if the first WT-infected mice were re-challenged with the non-expressing PTX strain ( $\triangle \mathrm{PTX}$ ) (Figure 2B). In accordance with this latter, we also observed that these $\mathrm{CD} 8^{+} \mathrm{Trm}$ are hyper-efficient against a new infection with WT B. pertussis strain. Indeed, only 12,500 transferred intra-tracheally in 
naïve mice are sufficient to favor elimination of WT strain (Figure 5). It would be interesting to test their efficiency against a $\triangle \mathrm{PTX}$ strain infection in naïve mouse.

In conclusion, we demonstrate in vivo that PTX is strictly required to generate lung Trms $\left(\mathrm{CD}^{+}, \mathrm{CD}^{+}\right.$and $\gamma \delta \mathrm{T}$ cells) against $B$. pertussis. Furthermore, our hypothesis was corroborated by increased $\mathrm{T}$ cell responses that were observed in mice co-administered $\triangle$ PTX with purified PTX. Further studies are needed to (i) define the exact role of Trm in long-term protection and to (ii) define their ontogeny.

Finally, deciphering the pivotal role of PTX (or PTX-producing B. pertussis) on the Trm generation can provide a new basis for PTX-mediated immunity with implications in vaccine strategies to improve long-term protection against $B$. pertussis.

\section{Materials and Methods}

\subsection{Bordetella Pertussis Strains and Growth Conditions}

To investigate impact of pertussis toxin (PTX), we used the wild B. pertussis Tohama I $(\mathrm{WT})$ and $\mathrm{Bp} \triangle \mathrm{PTX}(\triangle \mathrm{PTX})$ strains. The $\triangle \mathrm{PTX}$ strain has a deletion of the pertussis toxin operon (Alonso et al., 2001). Bacteria were grown on Bordet-Gengou blood agar plates for 4 days at $37^{\circ} \mathrm{C}$. Subsequently, multiple colonies were transferred onto new plates and grown for 2 days at $37^{\circ} \mathrm{C}$ prior to experimental infection.

\subsection{Mice}

This study was carried out in strict accordance with the guide lines of the Council of the European Union (Directive 86/609/EEC) regarding the protection of animals used for experimental and other scientific purposes. The experimental protocol was approved by the institutional animal care and use committee of the Aix-Marseille University ( ${ }^{\circ}$ 04287.01, acceptance 28 March 2017). All experiments were done in accordance with French and European guidelines for animal care. Seven-week-old females BALB/c (Janvier Laboratories; Le Genest St Isle France) were maintained under Animal Biosafety Level 2 facility and fed food and water ad libitum.

\subsection{Infection Model}

B. pertussis grown on Bordet-Gengou plates was suspended in ice-cold sterile PBS and adjusted to a concentration of $3 \times 10^{8} \mathrm{CFU} / \mathrm{mL}$. Primary infections were performed by the intra-nasal route with $20 \mu \mathrm{L}$ of the bacterial suspension $\left(6 \times 10^{6} \mathrm{CFU}\right)$ deposited in the nostrils of 7 week-old female Balb/c mice, anesthetized with $200 \mu \mathrm{L}$ of a Rompun-Ketamin mix by peritoneal injection. Six weeks later, secondary infections were performed by the same method than previously described.

\subsection{Fingolimod Treatment}

For FTY720 experiment (item $\mathrm{n}^{\circ} 10006292$, Cayman Chemical Company, Ann Arbor, MI, USA), mice were treated with $8 \mathrm{mg} / \mathrm{mL}$ of FTY720 in drinking water $24 \mathrm{H}$ before intranasal infection with B. pertussis. After infection, FTY720 was daily added in drinking water during the 5 days of the experiment.

\subsection{BrdU Pulse Chase Experiment}

For 5-Bromo-2'-deoxyuridine (BrdU) experiment (B500-2, Sigma-Aldrich, Saint Quentin Fallavier, France), mice were injected with $100 \mu \mathrm{L}$ of $\mathrm{BrdU}(10 \mathrm{mg} / \mathrm{mL})$ by peritoneal injection during infection. After infection, $667 \mu \mathrm{g} / \mathrm{mL}$ of BrdU were daily added in drinking water during the 5 days of the experiment.

\subsection{Pertussis Toxin Complementation}

For PTX complementary experiment, 100 ng of purified PTX (70323-44-3, TOCRIS, Noyal Châtillon sur Seiche, France) was added in $\triangle \mathrm{PTX}$ strain culture or in PBS solution during infection. 


\subsection{Isolation of Lymphocytes \\ 4.7.1. Lungs}

Lungs were removed from the mouse after perfusion of the heart with PBS. Lungs were cut into very small pieces (approximately $1-2 \mathrm{~mm}^{3}$ ) in gentleMACS C Tubes (MiltenyiBiotech, Paris, France) containing $3 \mathrm{~mL}$ of digestion solution (DNASE I $10 \mathrm{mg} / \mathrm{mL}$ (Sigma-aldrich, Saint Quentin Fallavier, France) + Collagenase II $70 \mathrm{mg} / \mathrm{mL}$ (Worthington, LS 004176, Serlabo technologies, Entraigues sur la Sorgue)) in 5\% RPMI medium. Lungs were cut into smaller pieces with the GentleMACS dissociator machine $(10 \mathrm{~s}$, MiltenyiBiotech). The lungs were digested at $37^{\circ} \mathrm{C}$ for $30 \mathrm{~min}$ under constant horizontal shaking (200 rpm) and then again grinded in the dissociator machine (45 s, MiltenyiBiotech, Paris, France). Stop buffer (1X PBS, 0.1 M EDTA) was added before filtering the lung digestion on $100 \mu \mathrm{m}$ strainer. With the help of a sterile syringe, the remaining lung pieces was push through the sieve. The sieve was washed with $5 \mathrm{~mL} \mathrm{RPMI} / 5 \%$ FCS, and the lung digestion was centrifuged at $400 \times g$ for $10 \mathrm{~min}$. The pellet were resuspended in $1 \mathrm{~mL}$ of red blood cell (RBC) lysis buffer (Sigma-Aldrich, Saint Quentin Fallavier, France) and incubated for $2 \mathrm{~min}$ at room temperature (RT). Nine $\mathrm{mL}$ of RPMI $/ 5 \% \mathrm{FCS}$ was added and then centrifuged at $400 \times g$ for $10 \mathrm{~min}, 4^{\circ} \mathrm{C}$. The pellet was resuspended in $2 \mathrm{~mL}$ of complete medium (RPMI-1640 supplemented with $50 \mu \mathrm{M} \beta$-mercaptoethanol, $1 \mathrm{mM}$ glutamine, $1 \%$ penicillin-streptomycin, $1 \%$ NEAA, $1 \%$ sodium pyruvate and 10\% FCS) for cell counting for cytometry analyses.

\subsubsection{Mediastinal Lymph Nodes (mLN) and Lymph Nodes (LN)}

$\mathrm{mLN}$ and LN (inguinal and axillary) were collected separately and crushed with the help of a sterile syringe through $100 \mu \mathrm{m}$ strainer in $3 \mathrm{~mL}$ of RPMI/5\% FCS. The suspension was then centrifuged at $400 \times g, 4^{\circ} \mathrm{C}$ for $8 \mathrm{~min}$. The $\mathrm{mLN}$ and LN pellets were resuspended in $600 \mu \mathrm{L}$ and $1 \mathrm{~mL}$ of complete medium for counting cells and for cytometry analyses, respectively.

\subsubsection{Bronchoaveolar Lavage Fluids (BALf)}

BALf was removed from the lungs by three consecutive expulsions/aspirations of $1 \mathrm{~mL}$ of PBS in the airway compartment via a thin cut realized in the upper part of the trachea. The lavage was then centrifuged at $400 \times \mathrm{g}$ for $10 \mathrm{~min}, 4^{\circ} \mathrm{C}$. The pellet was resuspended in $500 \mu \mathrm{L}$ of RBC lysis buffer and incubated for $2 \mathrm{~min}$ at RT. Nine $\mathrm{mL}$ of RPMI $/ 5 \%$ FCS were added for centrifugation at $400 \times g$ for $5 \mathrm{~min}, 4{ }^{\circ} \mathrm{C}$. The pellet was then resuspended in $200 \mu \mathrm{L}$ of complete medium and stored on ice until staining.

\subsubsection{Spleen}

Splenocytes were prepared by passing through the spleen on a $70 \mu \mathrm{m}$ sieve with the help of a sterile syringe in $6 \mathrm{~mL}$ RPMI $/ 5 \%$ FCS. The cell suspension was then centrifuged at $400 \times g, 4{ }^{\circ} \mathrm{C}$ for $10 \mathrm{~min}$. Then, splenocytes were treated as described for the lung.

\subsubsection{Blood}

Whole blood from infected or control mice obtained by cardiac puncture was mixed with a solution containing $1.5 \mathrm{mM}$ EDTA and $2 \%$ dextran and incubated at $37^{\circ} \mathrm{C}$ for $30 \mathrm{~min}$. Leukocyte-rich plasma, located on the top of the aggregated erythrocytes, was carefully collected and centrifuged at $400 \times g$ for $10 \mathrm{~min}$ at $4{ }^{\circ} \mathrm{C}$. The cell pellets were mixed with $3 \mathrm{~mL} \mathrm{RBC} \mathrm{lysis} \mathrm{buffer} \mathrm{for} 3 \mathrm{~min}$ and washed with RPMI-1640 containing 5\% FCS. Cells were stained for flow cytometry analysis.

\subsubsection{Intracellular Staining}

For basal cytokines detection, lung suspensions were cultured at $1 \times 10^{6}$ cells $/ \mathrm{mL}$ in a 6/well plate and stimulated with $50 \mathrm{ng} / \mathrm{mL}$ PMA (Sigma-Aldrich, Saint Quentin Fallavier, France) and $5 \mu \mathrm{g} / \mathrm{mL}$ ionomycin (Sigma-Aldrich, Saint Quentin Fallavier, France) in the presence of brefeldin A ( $1 \mu \mathrm{L}$ of GolgiPlug, BD Biosciences in $1 \mathrm{~mL}$ of complete RPMI 
medium). After $4 \mathrm{~h}$ of incubation at $37^{\circ} \mathrm{C}$ with $5 \% \mathrm{CO}_{2}$, cells were washed twice with PBS and incubated in FC blocker solution (2.4G2 FcR Block, produced in our laboratory) during $15 \mathrm{~min}$ on ice. Cells were then stained with surface antibodies including antiCD3, CD4, CD8, CD62L, CD69, CD103 and CD44; then, they were washed twice with PBS and stained with viability dye (eFluor-506, Thermofisher, Illkirch, France). Before staining with intracellular or transcriptional antibodies against IFN- $\gamma$, IL-17A, IL-10, IL2, IL-4, TNF- $\alpha$ and ROR $\gamma \mathrm{t}$, cells were treated with BDcytofix solution and washed by Perm/Wash solution (both from BD biosciences, Le Pont de Claix, France) according to the manufacturer's protocol. Finally, cells were washed with Perm/Wash and resuspended in PBS for FACS analysis.

BrdU incorporation was detected using the BrdU Flow kit ( $n^{\circ} 552598$, BD Biosciences Le Pont de Claix, France) according to the manufacturer's protocol. First, single-cell suspensions were isolated from the tissue of mice received FTY720/Brdu treatment. After staining of surface antigens, cells were treated with Cytofix/Cytoperm buffer for $30 \mathrm{~min}$ at RT. Cells were washed with Perm/Wash Buffer and fixed with Cytoperm Permeabilization Buffer Plus for 15 min. Cells were again washed with Perm/Wash buffer and were treated with Cytofix/Cytoperm for $10 \mathrm{~min}$. Then, cells were incubated with DNase I $(0.33 \mathrm{mg} / \mathrm{mL}$ in PBS) for $1 \mathrm{~h}$ at $37^{\circ} \mathrm{C}$ before cells were stained with an antibody mixture for BrdU and other intracellular markers in Perm/Wash Buffer for $30 \mathrm{~min}$ at RT. Cells were then washed twice with Perm/Wash Buffer and resuspended in PBS for FACS.

\subsection{FACS Analyses}

All antibodies used for flow cytometry were purchased from eBioscience, BD Biosciences or BioLegend. Dead cells were discriminated in all experiments using Live/dead (BV-510) fixable dead stain (Thermofisher, Illkirch, France). All stains were carried out with FC-block. Cell suspensions were stained 20-30 min on ice by the following mABs: CD3eeFlour450 (17A2), CD335-APC/eFlour780 (29A1.4), Ror $\gamma \mathrm{t}-\mathrm{APC}$ (B2D), CD8-BV711 (53-6.7),

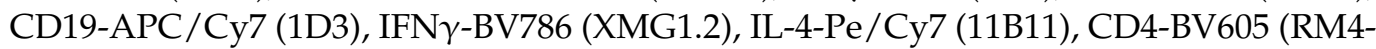
5), CD62L-Pe/Cy5 (MEL-14), CD44-Alexa700 (IM7), CD69-Pe/Cy7 or Pe/Cy5 (H1.2F3), CD103 (Itg $\alpha$ E)-PerCP/Cy5.5 (2E7), CD11b-APC/Cy7 (M1/70), TNF $\alpha$-APC/Cy7 (MP6XT22), IL-2-PE (JES6-5H4), IL-17-AF488 (TC11-18H10.1), IL-10-PE/Dazzle594 (JES5-16E3), CD90.1- APC (OX-7) and CD90.2-BV510 (30-H12). In all flow cytometric plots, doublets, dead cells and CD19+CD335+CD11b+ (dump channel) were excluded and the populations were gated as follows: CD4+T cells (CD3+CD4+), CD8+ T cells (CD3+CD8+), activated CD4+/CD8+T cells (CD3+CD4+CD44+CD62L-) and Trm (CD3+ CD4+/CD8+ CD62LCD44+CD69+CD103+). Cell acquisition was performed on a LSR II UV analyzer (BD Biosciences, Le Pont de Claix, France) using FACSDiva software (BD Biosciences), and data were analyzed using FlowJo software version 10.

\subsection{Cell Sorting and Adoptive Transfer}

Lungs and MLN were removed from donor mice (CD90.2+). Cells were prepared as previously described above. T cells were enriched negatively by using Pan T kit supplemented with CD62L antibody (MiltenyiBiotec, Paris, France). After, CD69+CD103+ Trm and CD69+CD103- subsets were sorted on an ARIAIII-SORP (BD Biosciences). Cellular purity of separated populations was determined by flow cytometric analysis and was routinely $>97 \%$. Sorted T cell subsets were prepared approximately $0.5-1.5 \times 10^{4}$ cells in $10 \mu \mathrm{L}$ of PBS and given intra-tracheally, or $1 \times 10^{6}$ cells in $100 \mu \mathrm{L}(\mathrm{Tnv})$, or $1 \times 10^{4}$ cells in $100 \mu \mathrm{L}$ (mLN) intra-venously to recipient mice (CD90.1+/CD90.2+). Three days later, the recipient mice were infected with $\mathrm{SM}$ as described above and euthanized at day 6 p.i. CFU counts were performed to access bacterial clearance and transferred cells were confirmed by FACS. 


\subsection{Immunostaining and FISH}

Perfused lungs were incubated for $4 \mathrm{~h}$ at $4{ }^{\circ} \mathrm{C}$ in Antigenfix solution (P0014, Diapath, Martinengo, Italia). Lungs were dehydrated overnight in 30\% sucrose solution and then frozen at $-80{ }^{\circ} \mathrm{C}$. Slices of $20 \mu \mathrm{m}$ were used for immunofluorescence or FISH staining. Trm were stained following the protocol described in Lelouard et al., 2012 [43] with the following panel: CD4-eF450, CD8 $\alpha$-AF488, CD69-AF568, CD103-AF647 or CD4-eF450, CD69-AF488, and CD103-Cya3. FISH protocol was done as described in (Pédron et al., 2012) [44], and the Eub338-Alexa-555 probe 5'-GCTGCCTCCCGTAGGAGT-3'was used to stain bacteria in the lung. All the images were taken on LSM 780 (Zeiss, Marly le Roi, France) confocal microscope. Series of $Z$ section were taken for each slides. Images were analyzed using Imaris 6.1.

\subsection{Statistical Analysis}

Statistical analyses were performed with GraphPad Prism software. The error bars show the standard deviation. For all the tests, we performed a Shapiro-Wilk test to assess for normality of data distribution. In case of normality, (i) when only two conditions were tested, we performed Welch $t$-test (since the validity of homoscedasticity hypothesis was never reached); (ii) when more than two conditions were compared, we performed a parametric one-way ANOVA, followed by Tukey test to assess the significance among pairs of conditions. In case of non-normality, (i) when only two conditions were tested, we performed a Mann-Withney U test; (ii) when more than two conditions were compared, we performed a non-parametric one-way ANOVA, followed by Dunn test to assess the significance among pairs of conditions.

\section{Patents}

IMPROVED PERTUSSIS VACCINE COMPOSITION: Ref: BEP180838 EP Patent $\mathrm{n}^{\circ}$ 18306831.1-1116.

Supplementary Materials: The following are available online at https://www.mdpi.com/article/ 10.3390/toxins13090632/s1, Figure S1: CD4+ CD69+CD103+ T cells subset is restricted to the lung. Figure S2: Pertussis Toxin (PTX) is required to generate CD8+ Trm subset in the lung of infected mice. Figure S3: CD4+ and CD8+ Trm subsets proliferate in the lung and are located at the front line of defense against $B$. pertussis. Figure S4: Cytokines production profiling of activated and $\mathrm{Trm} \mathrm{CD} 4^{+} \mathrm{T}$ cells. Figure S5: Pertussis Toxin Ptx promotes $\gamma \delta$ Trm cells and helps the bacteria to better colonize the lung of infected mice. Figure S6: Pertussis Toxin PTX is critique to generate Trm populations.

Author Contributions: J.T., Y.K., D.P., V.A.-G., S.H. and C.M. performed and analyzed the experiments. J.T., S.H., J.-P.G. and C.M. designed the experiments and J.T. and C.M. wrote the manuscript. J.T. and Y.K. contributed equally to this work. J.-P.G. and C.M. co-directed this work. All authors have read and agreed to the published version of the manuscript.

Funding: This research funded by ANR-11-LABEX_INFORM, grant number 0054 and "The ANRRECRUTE grant number RPV16003AAA".

Institutional Review Board Statement: This study was carried out in strict accordance with the guide lines of the Council of the European Union (Directive 86/609/EEC) regarding the protection of animals used for experimental and other scientific purposes. The experimental protocol was approved by the institutional animal care and use committee of the Aix-Marseille University ( ${ }^{\circ}$ 04287.01, acceptance 28 March 2017). All experiments were done in accordance with French and European guidelines for animal care.

Informed Consent Statement: Not Applicable.

Data Availability Statement: The data presented in this study are available on request from the corresponding author. The data are not publicly available due to the patent (BEP180838 EP Patent ${ }^{\circ}$ 18306831.1-1116). 
Acknowledgments: First we want to thank D. Raze and C. Locht for the providing of B. pertussis Tohama I (WT) and Bp $\triangle \mathrm{PTX}(\triangle \mathrm{PTX})$ strains. We thank O. Théodoly and AM Lellouch for the help they provided to $\mathrm{Y}$. Koo on the biophysical aspects of this project (not shown). We thank, Hugues Lelouard, Clement da Silva, Camille Wagner, and Emilie Narni-Mancinelli for help and scientific comments and discussions; ImagImm photonic microscopy and Flowcytometry facilities of the CIML and Christophe Duperray from the sorting facility of the MRI-IRB in Montpellier. We also thank D. Dombrowicz (Pasteur Institute, Lille, France) for providing the CD90.1+/+ mouse strain.

Conflicts of Interest: The authors declare no conflict of interest.

\section{References}

1. Yeung, K.H.T.; Duclos, P.; Nelson, E.A.S.; Hutubessy, R.C.W. An update of the global burden of pertussis in children younger than 5 years: A modelling study. Lancet Infect. Dis. 2017, 17, 974-980. [CrossRef]

2. Connelly, C.E.; Sun, Y.; Carbonetti, N.H. Pertussis Toxin Exacerbates and Prolongs Airway Inflammatory Responses during Bordetella pertussis Infection. Infect. Immun. 2012, 80, 4317-4332. [CrossRef]

3. Aricò, B.; Gross, R.; Smida, J.; Rappuoli, R. Evolutionary relationships in the genus Bordetella. Mol. Microbiol. 1987, 1, 301-308. [CrossRef]

4. Mangmool, S.; Kurose, H. Gi/o Protein-Dependent and -Independent Actions of Pertussis Toxin (PTX). Toxins 2011, 3, 884-899. [CrossRef]

5. Locht, C. A proposed mechanism of ADP-ribosylation catalyzed by the pertussis toxin S1 subunit. Biochimie 1995, 77, 333-340. [CrossRef]

6. Mills, K.H.; Barnard, A.; Watkins, J.; Redhead, K. Cell-mediated immunity to Bordetella pertussis: Role of Th1 cells in bacterial clearance in a murine respiratory infection model. Infect. Immun. 1993, 61, 399-410. [CrossRef]

7. Ross, P.J.; Sutton, C.E.; Higgins, S.; Allen, A.C.; Walsh, K.; Misiak, A.; Lavelle, E.; McLoughlin, R.; Mills, K.H.G. Relative Contribution of Th1 and Th17 Cells in Adaptive Immunity to Bordetella pertussis: Towards the Rational Design of an Improved Acellular Pertussis Vaccine. PLoS Pathog. 2013, 9, e1003264. [CrossRef]

8. Raeven, R.H.M.; Brummelman, J.; Pennings, J.L.; Nijst, O.E.M.; Kuipers, B.; Blok, L.; Helm, K.; Van Riet, E.; Jiskoot, W.; Van Els, C.A.C.M.; et al. Molecular Signatures of the Evolving Immune Response in Mice following a Bordetella pertussis Infection. PLoS ONE 2014, 9, e104548. [CrossRef]

9. Turner, D.L.; Farber, D.L. Mucosal Resident Memory CD4 T Cells in Protection and Immunopathology. Front. Immunol. 2014, 5, 331. [CrossRef]

10. Mackay, L.K.; Minnich, M.; Kragten, N.A.M.; Liao, Y.; Nota, B.; Seillet, C.; Zaid, A.; Man, K.; Preston, S.; Freestone, D.; et al. Hobit and Blimp1 instruct a universal transcriptional program of tissue residency in lymphocytes. Science 2016, 352, 459-463. [CrossRef]

11. Mackay, L.; Rahimpour, A.; Ma, J.; Collins, N.C.; Stock, A.T.; Hafon, M.-L.; Vega-Ramos, J.; Lauzurica, P.; Mueller, S.; Stefanovic, T.; et al. The developmental pathway for CD103+CD8+ tissue-resident memory T cells of skin. Nat. Immunol. 2013, 14, $1294-1301$. [CrossRef]

12. Mackay, L.K.; Kallies, A. Transcriptional Regulation of Tissue-Resident Lymphocytes. Trends Immunol. 2017, 38, 94-103. [CrossRef]

13. Rosato, P.C.; Beura, L.K.; Masopust, D. Tissue resident memory T cells and viral immunity. Curr. Opin. Virol. 2017, 22, 44-50. [CrossRef]

14. Szabo, P.A.; Miron, M.; Farber, D.L. Location, location, location: Tissue resident memory T cells in mice and humans. Sci. Immunol. 2019, 4, eaas9673. [CrossRef]

15. Gebhardt, T.; Whitney, P.; Zaid, A.; Mackay, L.; Brooks, A.; Heath, W.; Carbone, F.R.; Mueller, S. Different patterns of peripheral migration by memory CD4+ and CD8+ T cells. Nat. Cell Biol. 2011, 477, 216-219. [CrossRef]

16. Mackay, L.K.; Braun, A.; Macleod, B.L.; Collins, N.; Tebartz, C.; Bedoui, S.; Carbone, F.R.; Gebhardt, T. Cutting Edge: CD69 Interference with Sphingosine-1-Phosphate Receptor Function Regulates Peripheral T Cell Retention. J. Immunol. 2015, 194, 2059-2063. Available online: https:/ / pubmed.ncbi.nlm.nih.gov/25624457/ (accessed on 13 August 2021). [CrossRef] [PubMed]

17. Wilk, M.M.; Misiak, A.; McManus, R.M.; Allen, A.C.; Lynch, M.A.; Mills, K.H.G. Lung CD4 Tissue-Resident Memory T Cells Mediate Adaptive Immunity Induced by Previous Infection of Mice with Bordetella pertussis. J. Immunol. 2017, 199, 233-243. [CrossRef]

18. Romagnoli, P.; Sheridan, B.S.; Pham, Q.-M.; Lefrançois, L.; Khanna, K.M. IL-17A-producing resident memory $\gamma \delta$ T cells orchestrate the innate immune response to secondary oral Listeria monocytogenes infection. Proc. Natl. Acad. Sci. USA 2016, 113, 8502-8507. [CrossRef]

19. Sheridan, B.S.; Pham, Q.-M.; Lee, Y.-T.; Cauley, L.S.; Puddington, L.; Lefrançois, L. Oral Infection Drives a Distinct Population of Intestinal Resident Memory CD8+ T Cells with Enhanced Protective Function. Immunity 2014, 40, 747-757. [CrossRef] [PubMed]

20. Klein, N.P.; Bartlett, J.; Rowhani-Rahbar, A.; Fireman, B.; Baxter, R. Waning Protection after Fifth Dose of Acellular Pertussis Vaccine in Children. N. Engl. J. Med. 2012, 367, 1012-1019. [CrossRef]

21. Winter, K.; Zipprich, J.; Harriman, K.; Murray, E.L.; Gornbein, J.; Hammer, S.J.; Yeganeh, N.; Adachi, K.; Cherry, J.D. Risk Factors Associated With Infant Deaths From Pertussis: A Case-Control Study. Clin. Infect. Dis. 2015, 61, 1099-1106. [CrossRef] 
22. Warfel, J.M.; Zimmerman, L.I.; Merkel, T.J. Acellular pertussis vaccines protect against disease but fail to prevent infection and transmission in a nonhuman primate model. Proc. Natl. Acad. Sci. USA 2014, 111, 787-792. [CrossRef]

23. Althouse, B.M.; Scarpino, S.V. Asymptomatic transmission and the resurgence of Bordetella pertussis. BMC Med. 2015, 13, 1-12. [CrossRef]

24. Wilk, M.M.; Borkner, L.; Misiak, A.; Curham, L.; Allen, A.C.; Mills, K.H.G. Immunization with whole cell but not acellular pertussis vaccines primes CD4 TRM cells that sustain protective immunity against nasal colonization with Bordetella pertussis. Emerg. Microbes Infect. 2019, 8, 169-185. [CrossRef]

25. Beura, L.K.; Mitchell, J.S.; Thompson, E.A.; Schenkel, J.; Mohammed, J.; Wijeyesinghe, S.; Fonseca, R.; Burbach, B.J.; Hickman, H.; Vezys, V.; et al. Intravital mucosal imaging of CD8+ resident memory T cells shows tissue-autonomous recall responses that amplify secondary memory. Nat. Immunol. 2018, 19, 173-182. [CrossRef]

26. Alonso, S.; Pethe, K.; Mielcarek, N.; Raze, D.; Locht, C. Role of ADP-Ribosyltransferase Activity of Pertussis Toxin in ToxinAdhesin Redundancy with Filamentous Hemagglutinin during Bordetella pertussis Infection. Infect. Immun. 2001, 69, 6038-6043. [CrossRef] [PubMed]

27. Raeven, R.H.M.; van der Maas, L.; Tilstra, W.; Uittenbogaard, J.P.; Bindels, T.H.E.; Kuipers, B.; van der Ark, A.; Pennings, J.L.A.; van Riet, E.; Jiskoot, W.; et al. Immunoproteomic Profiling of Bordetella pertussis Outer Membrane Vesicle Vaccine Reveals Broad and Balanced Humoral Immunogenicity. J. Proteome Res. 2015, 14, 2929-2942. [CrossRef] [PubMed]

28. Carbonetti, N.H.; Artamonova, G.V.; Mays, R.M.; Worthington, Z.E.V. Pertussis Toxin Plays an Early Role in Respiratory Tract Colonization by Bordetella pertussis. Infect. Immun. 2003, 71, 6358-6366. [CrossRef] [PubMed]

29. Ayala, V.I.; Teijaro, J.R.; Farber, D.L.; Dorsey, S.G.; Carbonetti, N.H. Bordetella pertussis Infection Exacerbates Influenza Virus Infection through Pertussis Toxin-Mediated Suppression of Innate Immunity. PLoS ONE 2011, 6, e19016. [CrossRef] [PubMed]

30. Teijaro, J.R.; Turner, D.; Pham, Q.; Wherry, E.J.; Lefrançois, L.; Farber, D. Cutting Edge: Tissue-Retentive Lung Memory CD4 T Cells Mediate Optimal Protection to Respiratory Virus Infection. J. Immunol. 2011, 187, 5510-5514. [CrossRef] [PubMed]

31. Anderson, K.G.; Sung, H.; Skon, C.N.; Lefrancois, L.; Deisinger, A.; Vezys, V.; Masopust, D. Cutting Edge: Intravascular Staining Redefines Lung CD8 T Cell Responses. J. Immunol. 2012, 189, 2702-2706. [CrossRef]

32. Lin, P.L.; Flynn, J.L. CD8 T cells and Mycobacterium tuberculosis infection. Semin. Immunopathol. 2015, 37, 239-249. [CrossRef] [PubMed]

33. Rossey, I.; Sedeyn, K.; De Baets, S.; Schepens, B.; Saelens, X. CD8+ T cell immunity against human respiratory syncytial virus. Vaccine 2014, 32, 6130-6137. [CrossRef]

34. Misiak, A.; Wilk, M.M.; Raverdeau, M.; Mills, K.H.G. IL-17-Producing Innate and Pathogen-Specific Tissue Resident Memory $\gamma \delta$ T Cells Expand in the Lungs of Bordetella pertussis-Infected Mice. J. Immunol. 2017, 198, 363-374. [CrossRef]

35. Spangrude, G.J.; Sacchi, F.; Hill, H.R.; E Van Epps, D.; A Daynes, R. Inhibition of lymphocyte and neutrophil chemotaxis by pertussis toxin. J. Immunol. 1985, 135, 4135-4143. [PubMed]

36. Poland, G.A.; Fleming, D.M.; Treanor, J.J.; Maraskovsky, E.; Luke, T.C.; Ball, E.M.; Poland, C.M. New Wisdom to Defy an Old Enemy. In Proceedings of the 4th Influenza Vaccines for the World (IVW) 2012 Congress, Valencia, Spain, 11 October 2012; pp. A1-A20. [CrossRef]

37. Greer, A.L.; Fisman, D.N. Use of Models to Identify Cost-effective Interventions: Pertussis Vaccination for Pediatric Health Care Workers. Pediatrics 2011, 128, e591-e599. [CrossRef] [PubMed]

38. Hong, J.Y. Update on pertussis and pertussis immunization. Korean J. Pediatr. 2010, 53, 629-633. [CrossRef] [PubMed]

39. Mueller, S.; Mackay, L. Tissue-resident memory T cells: Local specialists in immune defence. Nat. Rev. Immunol. 2016, 16, 79-89. [CrossRef]

40. Hombrink, P.; Helbig, C.; Backer, R.A.; Piet, B.; Oja, A.E.; Stark, R.; Brasser, G.; Jongejan, A.; Jonkers, R.E.; Nota, B.; et al. Programs for the persistence, vigilance and control of human CD8+ lung-resident memory T cells. Nat. Immunol. 2016, 17, 1467-1478. [CrossRef]

41. Higgs, R.; Higgins, S.C.; Ross, P.J.; Mills, K.H.G. Immunity to the respiratory pathogen Bordetella pertussis. Mucosal Immunol. 2012, 5, 485-500. [CrossRef]

42. Coleman, M.; Finlay, C.; Moran, B.; Keane, J.; Dunne, P.J.; Mills, K. The immunoregulatory role of CD4+FoxP3+CD25-regulatory $\mathrm{T}$ cells in lungs of mice infected with Bordetella pertussis. FEMS Immunol. Med Microbiol. 2012, 64, 413-424. [CrossRef] [PubMed]

43. Lelouard, H.; Fallet, M.; de Bovis, B.; Meresse, S.; Gorvel, J.-P. Peyer's Patch Dendritic Cells Sample Antigens by Extending Dendrites Through M Cell-Specific Transcellular Pores. Gastroenterology 2012, 142, 592-601.e3. [CrossRef] [PubMed]

44. Pédron, T.; Mulet, C.; Dauga, C.; Frangeul, L.; Chervaux, C.; Grompone, G.; Sansonetti, P.J. A Crypt-Specific Core Microbiota Resides in the Mouse Colon. mBio 2012, 3, e00116-12. [CrossRef] [PubMed] 